\title{
Akar Krisis Ekonomi Global dan Dampaknya Terhadap Indonesia
}

\author{
Oleh: Edy Suandi Hamid ${ }^{1}$
}

\begin{abstract}
In the last two years, the world economy witnesses three type of crises emerging, namely fuel, food, and financial crises. Facing this crisis, Indonesian economy should indeed be ready for any short-term and long-term shocks to maintain sustainability of its performance. Based on these situations, this paper is aimed to oversee the nature of financial crisis and its effect on Indonesian economy. The study in this paper indicates that current financial crisis is an undeniable evidence of capitalism failure mainly caused by its paradigm and basic ideas which neglect the humanity. For this reason, turning economics back to meet the human needs and its philosophy is urgently required. Indonesia is still affected by current financial crisis and it is an important moment to evaluate capitalism-oriented economic policies as well as to oversee its suitable nature economic system which is relevant to the way of its people life.
\end{abstract}

Keyword: financial crisis, Indonesian economy, market fundamentalism.

\section{Pendahuluan}

Tahun 2007 hingga 2008 ini menjadi tahun yang amat berat bagi ekonomi dunia. Setelah krisis bahan bakar (fuel) dan pangan (food), saat ini ekonomi dunia dihadapkan pada krisis finansial (financial) yang dampaknya telah begitu terasa dan masih akan terus berlangsung. Untuk krisis terakhir, yaitu krisis finansial, karena berasal dari Amerika Serikat (AS), pelaku nomor satu ekonomi dunia saat ini, maka dampaknya berimbas pada lebih banyak bidang dan melibatkan lebih banyak negara, termasuk Indonesia. Alan Greenspan, mantan Gubernur Bank Sentral AS (The Fed) bahkan menyebut krisis ini sebagai 'once-in-century' financial crisis-nya yang akan dan terus membawa dampak terhadap perekonomian global. International Monetary Fund (IMF) bahkan menyebutnya sebagai 'largest financial shock since Great Depression', yang menandakan betapa dalam krisis telah terjadi.

Bagi sebagian besar masyarakat Indonesia, dampak krisis jelas sudah demikian terasa. Selain jatuhnya nilai IHSG di Bursa Efek Indonesia hingga penutupan aktivitas bursa beberapa waktu lalu, dampak krisis juga nampak dari mulai turunnya omset ekspor produk-produk Indonesia ke pasaran dunia, terutama AS, termasuk juga yang dikelola oleh pengusaha bidang UKM. Pemerintah sendiri juga telah melakukan berbagai upaya antisipatif menghadapi kemungkinan terburuk dari krisis tersebut. Paparan berikut dimaksudkan untuk melihat sejauh mana kemampuan ekonomi nasional dalam menghadapi krisis yang tengah berlangsung, sekaligus mencoba melihat alternatif solusi jangka panjang bagi ekonomi Indonesia.

1 Guru Besar Ilmu Ekonomi Program Studi Ilmu Ekonomi Fakultas Ekonomi UII. E-mail: edysuandi@fe.uii.ac.id

Volume III, No. 1, Juli 2009 . 
Edy Suandi Hamid: Akar Krisis Ekonomi Global...

\section{Krisis Finansial dan Wajah Kapitalisme Global}

Krisis keuangan (financial crisis) biasanya diartikan sebagai situasi dimana lembaga keuangan atau aset kehilangan nilai dalam jumlah yang besar. Perkembangan selanjutnya di abad 19 dan 20, krisis keuangan juga dianalogikan dengan krisis yang melanda dunia perbankan dan sejumlah resesi dengan dampak yang juga besar. Termasuk dalam kategori krisis keuangan ini antara lain adalah krisis di bursa saham, krisis mata uang dan juga sovereignity. ${ }^{2}$

Dalam krisis keuangan AS, sejumlah pandangan bermunculan mengenai sebab utama yang melatarbelakangi krisis. Stiglitz, peraih Nobel Ekonomi 2001, menyebutkan bahwa krisis keuangan AS terjadi sebagai akibat kesalahan di hampir semua putusan ekonomi yang dalam bahasa arsitek kerap disebut 'system failure'. System failure ini, menurut Stiglitz, telah dimulai sejak pergantian Paul Volcker --yang lebih memandang perlunya pengaturan dalam pasar keuangan-- oleh Alan Greenspan sebagai Chief The Fed. Pilihan kebijakan lain yang juga menjadi akar krisis, antara lain terlihat dari kebijakan-kebijakan di sekitar Wall Street yang cenderung memberi perlindungan lebih kepada dunia perbankan AS dalam spekulasi dan derivasi produk keuangan, kebijakan anggaran di masa George W. Bush, dan ketidakacuhan terhadap sejumlah skandal keuangan yang sebelumnya telah terjadi seperti dalam kasus Enron dan Worldcom. ${ }^{3}$

Senada dengan Stiglitz, Barry Eichengreen, melihat akar krisis selain berasal dari keserakahan pelaku pasar (greed and corruption on Wall Street) juga menunjukkan beberapa kebijakan ekonomi dalam beberapa dasawarsa terakhir sebagai sebab utama terjadinya krisis. Deregulasi di pasar saham pada tahun 1970-an mengawali langkah perbankan yang aktif mencari dana dari produk-produk derivatif melalui pasar modal. Kebijakan ekonomi AS yang dissaving juga membuat resesi pada 2001 yang kemudian membuat kredit menjadi demikian mudah diperoleh dalam jumlah besar oleh sebagian keluarga di AS. Eichengreen juga menilai kesalahan merespon perkembangan ekonomi China sebagai salah satu faktor penggerak tidak efektifnya kebijakan keuangan The Fed yang pada akhirnya berdampak pada krisis. ${ }^{4}$

Dalam kerangka ekonomi Islam, Fahim Khan melihat krisis berasal dari kesalahan mendasar praktek ekonomi yang melindungi institusi keuangan dan perbankan untuk bermain dan berspekulasi (gambling and speculation) di pasar keuangan. Untuk itu, solusi strategis yang layak dikemukakan adalah dengan melakukan reformasi di pasar barang dan jasa sehingga memungkinkan pasar untuk memenuhi instrumen keuangannya sendiri yang sesuai dengan kebutuhan masyarakat sekitarnya tanpa harus terlibat dengan pasar keuangan. ${ }^{5}$

2 Wikipedia (2008), Financial crisis, dikutip dari http://en.wikipedia.org/wiki/Financial_crisis/accessed 22 Oktober 2008.

${ }^{3}$ Joseph Stiglitz (2009), Capitalist Fools dikutip dari http://www.vanityfair.com/magazine/2009/01 /stiglitz200901?printable=true\&currentPage/ accessed 10 Desember 2008.

${ }^{4}$ Barry Eichengreen (2008). Anatomy of Financial Crisis dikutip dari http://www.voxeu. org/index. php?q=node $/ 1684 /$ accesed 23 September 2008.

${ }^{5}$ M. Fahim Khan (2008), World Financial Crisis :Lesson from Islamic Economics dikutip dari http://www.isei.org/accessed 28 November 2008. 
Edy Suandi Hamid: Akar Krisis Ekonomi Global...

Harus diakui, krisis finansial yang tengah berlangsung saat ini tidak bisa dilepaskan dari the nature of capitalism yang mengakar pada sistem ekonomi mainstream yang saat ini diusung AS dan sebagian besar negara di dunia. Dalam sistem ekonomi kapitalisme, pasar selalu diyakini memiliki kemampuan self-correcting yang menjamin tercapainya equilibrium setiap kali terjadi gejolak. Market fundamentalisme yang telah menjadi ideologi dominan ini kemudian menjadi pegangan yang menyebabkan maraknya transaksi berbasis spekulasi yang hanya menambah menggelembungnya ekonomi tapi tanpa pijakan yang riil dan kuat (bubble economy), dan tinggal menunggu waktu untuk meledak sehingga menimbulkan krisis berikut dampak dan efek negatifnya bagi perekonomian.

Keyakinan berlebihan dalam market fundamentalisme juga berakibat pada alpanya sebagian besar pelaku ekonomi, bahwa otoritas keuanganlah yang kerap kali berjasa dan harus bertindak setiap kali terjadi krisis. Dalam kasus AS, sejak 1980, sejumlah krisis juga telah terjadi, antara lain krisis perbankan internasional 1982, bangkrutnya Continental Illinois 1984, dan kegagalan Long-Term Capital Management 1998, dan pada setiap krisis, otoritas keuanganlah yang megucurkan dana untuk menolong perekonomian bangkit kembali atau setidaknya mengambil inisiatif untuk hal tersebut. ${ }^{6}$

Pengalaman Indonesia dalam krisis 1997-1998 yang lalu juga menunjukkan bagaimana kegagalan pasar yang berdampak buruk bagi perekonomian juga menuntut partisipasi pemerintah untuk mengatasi dampak krisis dengan mengalirkan dana untuk menyelamatkan perekonomian nasional. Dana yang dialirkan untuk membantu pelaku-pelaku ekonomi (umumnya bank yang kolaps) ini tentu saja berasal dari rakyat yang diserap melalui pajak dan sumber pendapatan lainnya. Hal ini menunjukkan bagaimana kegagalan pasar dalam kapitalisme sebagai akibat perilaku spekulatif dari pelaku pasar harus dibayar oleh rakyat yang justru tidak pernah menikmati hasil dari sistem ekonomi pasar tersebut.

Hal yang lebih memperihatinkan adalah fakta bahwa asal muasal krisis sebenarnya adalah kesalahan (atau lebih tepatnya ketamakan) perusahaan finansial dalam mengalokasikan dananya pada kredit perumahan sub-prima (subprime mortgage). Kesalahan ini dengan sendirinya menunjukkan kelemahan mendasar dari sistem ekonomi kapitalis yang semata-mata mendasarkan proyeksi bisnis pada spekulasi atas kemungkinan pendapatan di masa mendatang, dan tanpa melihat realitas dunia ekonomi yang tengah berlangsung. Bencana keuangan pun kemudian melanda setelah kredit macet terjadi dan melumpuhkan sejumlah raksana finansial yang memback-up-nya. Mulai dari bangkrutnya bank raksasa Lehman Brothers dan perusahaan finansial raksasa Bear Stearns. Beberapa saat sebelumnya, pemerintah AS juga terpaksa telah mengambil alih perusahaan mortgage terbesar di Amerika; Freddie Mac dan Fannie Mae Sementara Merrill Lynch mengalami kondisi tak jauh beda hingga harus diakuisisi oleh Bank of America. Terakhir perusahaan asuransi terbesar AIG (American International Group) menunjukkan gejala kritis yang sama.

Untuk mengatasi badai krisis yang hebat itu dan menyelamatkan bank-bank raksasa yang terpuruk, pemerintah Amerika Serikat terpaksa melakukan bailout

${ }^{6}$ The New York Time Review of Books (2008), The Financial Crisis: An Interview with George Soro. diakses pada 22 Oktober 2008

Volume III, No. 1, Juli 2009 
Edy Suandi Hamid: Akar Krisis Ekonomi Global...

sebesar 700 milyar dolar sampai 1 triliun US dolar. Intervensi negara terhadap sektor keuangan di AS tersebut, selain merupakan kebijakan yang bertentangan dengan kapitalisme, juga dinilai belum akan mampu menyelamatkan krisis yang terus akan terjadi. Kebijakan bailout tidak saja dilakukan pemerintah AS, tetapi juga bank sentral Eropa dan Asia turun tangan menyuntikkan dana untuk mendorong likuiditas perekonomian, sehingga diharapkan dapat mencegah efek domino dari ambruknya bank-bank investasi kelas dunia tersebut.

Beberapa saat setelah informasi kebangkrutan Lehman Brothers, pasar keuangan dunia mengalami terjun bebas di tingkat terendah. Beberapa bank besar yang collaps dan runtuhnya berbagai bank investasi lainnya di AS segera memicu gelombang kepanikan di berbagai pusat keuangan seluruh dunia. Pasar modal di AS, Eropa dan Asia segera mengalami panic selling yang mengakibatkan jatuhnya indeks harga saham pada setiap pasar modal.

Efek domino dalam perekonomian dunia akibat krisis finansial AS ini memang merupakan konsekuensi logis dari model perekonomian global yang makin terbuka dan menghapuskan batasan-batasan antar negara. Akibatnya semua pelaku ekonomi dunia rentan terkena dampaknya, terlepas dari fakta bahwa pelaku tersebut ikut menikmati hasil perekonomian tersebut ataupun tidak. Disinilah kemudian pertanyaan mendasar mengenai kapitalisme sebagai sebuah sistem ekonomi layak untuk dikemukakan. Benarkah pasar mampu menentukan sendiri dengan tepat dan efisien alokasi ekonomi terbaik bagi masyarakat? Benarkah pasar juga mampu memberikan keadilan bagi seluruh pelaku ekonomi dunia?

Dalam konteks ekonomi global saat ini, globalisasi yang arahnya dianggap menguntungkan pemodal kuat sering disamakan dengan kapitalisme global. Melalui globalisasi inilah wajah kapitalisme global yang serakah bekerja sedemikian rupa menghancurkan banyak sendi-sendi kehidupan ekonomi dunia. Hal inilah yang memunculkan penolakan pada cara-cara kapitalis tersebut. Namun demikian gerakan penolakan pada kapitalisme global ini tidak sepenuhnya homogen. Alex Callinicos menyatakan bahwa gerakan antikapitalis adalah jauh dari suatu gerakan yang secara ideologis homogen. Kelompok borjuis anti-kapitalis dapat menerima pandangan neo-liberal bahwa kapitalisme menawarkan solusi pada masalah kemanusiaan (bumankind), namun mengritik faham tersebut untuk lebih responsif atas kritik berkaitan dengan pewujudan masyarakat madani (civil society).

Sementara itu gerakan global anti-kapitalis menuntut pengembangan hubungan mikro di antara produsen dan konsumen yang dapat mendukung keadilan sosial dan kemandirian ekonomi, karenanya pasar harus diarahkan untu tujuan tersebut. Sedangkan gerakan reformis anti kapitalis menuntut adanya pengaturan pada kapitalisme seoperti pasca perang dunia. Di sisi lain, gerakan sosialis anti kapitalis menyatakan hanya satu alternatif bagi kapitalisme untuk konsisten dengan modernisasi, yakni ekonomi perencanan yang demokratis (democratically planned economy) ${ }^{7}$

Mengapa realisasi tujuan globalisasi, yakni meningkatkan kesejahteraan dunia serta menghapuskan kemiskinan tidak terwujud? Satu hal yang menjadi penyebab

7 Alex Callinicos (2003), An Anti-Capitalist Manifesto (Cambridge: Polity Press), p. 104-105. 
Edy Suandi Hamid: Akar Krisis Ekonomi Global...

utamanya adalah suatu kenyataan bahwa kekuatan ekonomi antarnegara yang berkompetisi bebas ini tidak seimbang. Padahal ini merupakan syarat utama untuk dapat mewujudkan terjadinya situasi yang saling menguntungkan dari adanya globalisasi ekonomi tersebut. Dengan kekuatan ekonomi yang tidak seimbang tersebut maka persaingan cenderung dimenangkan oleh yang kuat, baik dalam sumber daya manusia, kapital, maupun teknologi. Dengan ketidakseimbangan kekuatan ekonomi yang ada, maka kecenderungan yang terjadi adalah pemaksaan arah globalisasi sesuai dengan kepentingan yang kuat.

Gagalnya perundingan WTO di Cancun merupakan contoh bagaimana negara-negara maju ingin memaksakan kehendak dalam globalisasi ekonomi dengan menuntut negara berkembang membuka pasarnya, sementara negara maju bertahan dengan tingkat proteksi untuk komoditi pertaniannya. Tuntutan negara berkembang sebetulnya merupakan sesuatu yang wajar sebagai negara negara yang menuntut adanya kesetaraan dengan negara-negara maju. Namun hal ini tidak dipenuhi negara-negara maju yang tidak mau menurunkan proteksi untuk melindungi para petani di negerinya. Kekompakan negara-negara berkembang pada forum tersebut telah mengakibatkan gagalnya forum tersebut untuk "didikte" negara maju, yang alokasi subsidi untuk petaninya jauh lebih besar dari bantuan yang diberikan kepada negara-negara berkembang.

\section{Meluruskan Kembali Ilmu Ekonomi}

Mengapa wajah kapitalisme global yang demikian menjadi trend utama ekonomi dunia? Jawabannya tentu saja tidak bisa dilepaskan dari paradigma keilmuan yang mendasarinya, yaitu ilmu ekonomi (economics) terutama dengan laissez-faire-nya yang menjadi arus utama dalam membingkai kebijakan ekonomi dunia. Hal ini mengindikasikan bahwa upaya memecah dampak negatif kapitalisme global, dengan sendirinya juga sangat berkaitan dengan upaya meluruskan kembali jalan dari ilmu ekonomi tersebut. Usaha "meluruskan " jalannya ilmu ekonomi yang kemudian menjadi sangat bangga karena disejejarkan dengan ilmu-ilmu yang eksak, sebenarnya sudah cukup lama berjalan. Munculnya pemikiran-pemikiran dari kelompok ekonomi kelembagaan (institutional economics) merupakan salah contoh pemikiran diluar mainstream economist yang mengingatkan kekeliruan perkembangan ilmu ekonomi yang terjadi selama ini.

Letupan-letupan ketidakpuasan pada ekonomi konvensional itu kemudian memunculkan berbagai konsep ilmu ekonomi alternatif, seperti Ekonomi Kelembagaan (Kenneth Building), Ekonomika Strukturalis (Raul Prebisch), serta Ekonomika Islami yang digali oleh ekonom-ekonom muslim. Di Indonesia sejak awal 1980-an ketidakpuasan atas teori ekonomi konvensonal itu sudah diwacanakan oleh Prof. Mubyarto, dan kini dikembangkan melalui PUSTEP (Pusat studi Ekonomi Pancasila) UGM. Ilmu ekonomi yang diakatakan semakin "canggih" ini sering dipertanyakan pula keterapannya dalam memecahkan masalah riil dalam perekonomian. Suatu studi di enam universitas tekemuka dunia (Chicago, Harvard, MIT, Stanford, Columbia, dan Yale) pada 1977 hanya 34\% mahasiswa pascasarjana yang menyatakan "sangat setuju" ilmu ekonomi yang diajarkan di universitasuniversitas AS relevan untuk memecahkan masalah ekonomi dewasa ini. ${ }^{8}$

${ }^{8}$ Mubyarto (2002), Ekonomi Kerakyatan dalam Era Globalisasi, Jurnal Ekonomi Rakyat, Th. 1 No. 7/2002, (Yogyakarta: PUSTEP UGM), p. 18.

Volume III, No. 1, Juli 2009 
Edy Suandi Hamid: Akar Krisis Ekonomi Global...

Perkembangan yang lebih maju bahkan terjadi di Universitas Harvard. Di perguruan tinggi yang sangat prestisius di dunia ini, telah ditawarkan mata kuliah pengantar ekonomi alternatif yang diajar oleh Prof Martien Feldstein, mantan penasihat ekonomi semasa Presiden AS Ronald Reagan. Menurut mingguan The Economist (10 Mei 2003) $)^{9}$, asumsi dasar pengajaran ini berbeda dengan yang diajarkan ekonom neo-klasik. Dengan menggunakan pendekatan psikologi, ekonom ini menolak konsep bomo-ekonomikus, yang selalu menganggap manusia bertindak rasional. Ini merupakan serangan yang mendasar pada ajaran ekonomi konvensional. Jika konsep ini diterima, maka dampaknya akan sangat luas bagi pengajaran ilmu ekonomi yang saat ini berbasiskan ekonomi neo-klasik.

Tulisan dalam rubrik "Fokus Ekonomi" bertajuk "Behaviourist at the Gates" itu menjelaskan bagaimana ekonom prilaku (behavioural economist) menggunakan psikologi untuk mempertanyakan resep-resep kebijakan ekonom ortodoks (konvensional). Ditawarkannya mata kuliah pengantar ekonomi altenatif di Harvard tersebut menunjukkan upaya yang dilakukan Prof. Mubyarto dan kawan-kawan, misalnya, dengan mengkaji dan merumuskan sistem ekonomi altenatif melalui Ekonomi Pancasila, yang di dalamnya secara tegas memasukkan unsur moral dan etika, bukanlah sesuatu yang aneh dan mengada-ada.

Kebutuhan akan ekonomi altenatif ini juga muncul dari kampus-kampus di Amerika di mana sebagian besar mahasiswa pertama kali memperoleh pengajaran mengenai konsep homo ekonomikus. Walaupun yang diajarkan para ekonom yang "murtad" (atau mungkin lebih pas disebut ekonom reformis, ekonom pembaharu) ini lebih jelas dibanding neo-klasik yang tidak rinci dalam menjelaskan perilaku manusia dalam dunia nyata. Walaupun hasil dari eksperimen atau upaya semacam ini masih terbatas, namun paling tidak sosialisasi pemikiran tersebut dapat berguna bagi para pengambil kebijakan ataupun pelaku ekonomi agar tidak "tersesat" terlalu jauh dalam melaksanakann aktivitas ekonomi ini. Dalam tahap awal, pemikiran ekonomi alternatif bisa menjadi "opini kedua" (second opinion) sebagai suatu pandangan yang tidak melulu mengajarkan manusia untuk berindak hanya berorientasi kebendaan atau keserakahan.

\section{Kondisi Ekonomi Indonesia Saat Ini}

Krisis subprime mortgage yang mengawali krisis finansial dunia saat ini, juga berimbas kepada perekonomian nasional melalui beberapa jalur, antara lain (a) jalur perdagangan langsung antara Indonesia dan Amerika Serikat; (b) jalur perdagangan Indonesia dan Asia/Eropa; (c) jalur (kenaikan) biaya pinjaman; (d) jalur (apresiasi) nilai tukar Rupiah; dan (e) jalur (suku bunga) kebijakan moneter Bank Sentral AS. ${ }^{10}$ Meskipun hanya berawal dari krisis KPR yang mengakibatkan kredit macet, krisis AS terbukti berdampak lebih besar antara lain mengingat keterkaitan sektor perumahan dengan sejumlah perusahaan dan pasar keuangan internasional.

${ }^{9}$ Pada bagian ini, sumber tulisan sebagian besar dari majalah the Economist tersebut.

10 Wahyu Partomo (2007), Ancaman Perlambatan dan Inflasi Amerika Serikat, Perkembangan Ekonomi Keuangan dan Kerja Sama Internasional - Triwulan III 2007 (Jakarta: Bank Indonesia), p. 83. 
Edy Suandi Hamid: Akar Krisis Ekonomi Global...

Secara umum kondisi makroekonomi Indonesia memang menunjukkan pelemahan akibat dari gejolak krisis AS ini (lihat Tabel 1). Namun secara umum kondisi makroekonomi ini relatif jauh lebih baik dibandingkan pada masa krisis moneter yang berimbas pada krisis ekonomi satu dasawarsa lalu. Episentrum krisis yang tidak berada di Indonesia, ditambah belum dominannya investor dalam negeri dalam memanfaatkan produk investasi luar negeri, dan posisi devisa yang aman untuk transaksi luar negeri setidaknya menjelaskan bagaimana kondisi ini bisa terjadi. Di sisi lain, kebijakan pengendalian inflasi melalui kenaikan BI Rate meskipun sedikit tetap berpengaruh positif dalam menjaga inflasi tetap dalam kondisi yang tidak membahayakan perekonomian nasional.

Sebagai salah satu pasar yang relatif tidak terproteksi, pasar keuangan Indonesia juga menjadi sasaran dampak krisis AS yang terus menyebar tersebut. Tak heran jika banyak pihak mengharapkan pemerintah untuk melakukan lebih banyak lagi tindakan untuk mengantisipasi agar krisis tidak meluas. Kekhawatiran bahwa krisis 1997-98 akan terulang, bahkan juga ikut melanda banyak pihak. Namun demikian, harus disadari bahwa dibandingkan kondisi pada masa krisis 1997-98 lalu, saat ini fundamental ekonomi nasional memang tampak memiliki kekuatan yang lebih baik. Beberapa indikator ekonomi menunjukkan hal tersebut, seperti tampak pada Tabel 2.

Tabel 1. Indikator Makroekonomi 2007.I s.d. 2008.III

\begin{tabular}{|l|l|l|l|l|l|l|l|}
\hline Indikator & $2007 . I$ & $2007 . I I$ & $2007 . I I I$ & $2007 . I V$ & $2008 . I$ & $2008 . I I$ & $2008 . I I I$ \\
\hline PDB (yoy) & 6,1 & 6,4 & 6,5 & 6,3 & 6,3 & 6,4 & 5,8 \\
\hline Pengangguran & 9,8 & n.a. & 9,1 & n.a. & 8,5 & - & - \\
\hline Inflasi IHK & 6,5 & 5,8 & 7,0 & 6,6 & 8,2 & 10,1 & 12,1 \\
\hline $\begin{array}{l}\text { Suku Bunga } \\
\text { BI Rate }\end{array}$ & 9,00 & 8,50 & 8,25 & 8,00 & 8,00 & 9,00 & 9,25 \\
\hline $\begin{array}{l}\text { Uang Beredar } \\
\text { (M2) }\end{array}$ & 15,1 & 15,8 & 17,1 & 18,9 & 15,3 & 17,1 & 12,6 \\
\hline $\begin{array}{l}\text { Cadangan } \\
\text { Devisa (US \$ } \\
\text { Miliyar) }\end{array}$ & 45,7 & 49,4 & 51,2 & 55,0 & 54,9 & 57,3 & 55 \\
\hline $\begin{array}{l}\text { Nilai Tukar } \\
\text { (US \$) }\end{array}$ & 9.111 & 8.969 & 9.239 & 9.238 & 9.260 & 9.257 & 9.223 \\
\hline
\end{tabular}

Sumber: Bank Indonesia, 2008, diolah.

Tabel 2. Perbandingan Indikator Ekonomi Nasional, Krisis 1997 dan Gejolak 2008

\begin{tabular}{|l|l|l|}
\hline Indikator & Krisis 1997 & Gejolak 2008 \\
\hline Depresiasi Rupiah & $100 \%$ & $5 \%$ \\
\hline Inflasi & $20 \%$ & $11,14 \%$ \\
\hline NPL Perbankan & $60 \%$ & $1 \%$ \\
\hline Suku Bunga SBI & $50 \%$ & $9,25 \%$ \\
\hline Suku Bungan PAUB & $200 \%$ & $12 \%$ \\
\hline Giro Bank Terhadap GWM & Minus Rp 2,6 T & Surplus Rp 3 Triliun \\
\hline Cadangan Devisa & US \$22,1 Miliar & US \$ 57 Miliar \\
\hline
\end{tabular}

Sumber: Dikutip dari Kompas, 13 Oktober 2008.

Volume III, No. 1, Juli 2009 
Edy Suandi Hamid: Akar Krisis Ekonomi Global...

Pemerintah sendiri dan juga Bank Indonesia telah melakukan sejumlah langkah pengamanan baik di sektor perbankan, pasar modal, maupun jaring pengaman sosial yang diharapkan mampu menahan dampak negatif dari imbas krisis. Namun demikian, dengan kondisi pasar yang demikian terbuka, berbagai dampak tetap akan terasa. Industri dan unit usaha termasuk UKM yang secara langsung berhubungan dengan pelaku ekonomi luar negeri (ekspor dan impor) merupakan yang paling awal merasakan dampak krisis. Hal ini menunjukkan bahwa konsentrasi kebijakan pada sektor riil harus lebih diutamakan.

\section{Langkah Strategis Jangka Panjang}

Kondisi krisis yang saat ini tengah berlangsung menunjukkan bahwa ekonomi nasional Indonesia telah dan terus terseret pada arus global. Terus mengembangkan pasar finansial yang tidak berbasis sektor riil, dengan pelaku ekonomi yang terbatas namun menentukan ekonomi nasional, dengan dominasi peran asing yang makin besar, dan keterlibatan sangat terbatas dari pemerintah untuk mempengaruhi perekonomian serta keberpihakan yang terbatas pada pelaku ekonomi rakyat. Situasi ini bukan saja membuat suatu ironi dimana negara yang kaya sumberdaya alam namun miskin dalam daya beli masyarakatnya, melainkan juga membuat kita terperangkap pada negara yang tergantung pada negara lain dan terjebak sebagai bangsa dengan kemiskinan yang besar.

Indonesia pun masuk dalam agenda-agenda liberalisme-pasar bebas yang digagas negara-negara maju, korporasi global, dan lembaga keuangan internasional, yang terbukti merugikan petani dan pelaku ekonomi rakyat lainnya. Oleh karena itu, terkait dengan kondisi saat ini, seharusnya mendesak pemerintah, DPR, dan elemen terkait untuk memproteksi perekonomian nasional. termasuk komoditas seperti pertanian sebagaimana yang dilakukan oleh negara maju dan tidak secara mudah terpedaya oleh kemauan negara-negara maju yang menggunakan jalur negosiasi untuk memaksakan kehendaknya.

Dalam konsep ekonomi kerakyatan sebagai subsistem dari ekonomi pancasila, seharusnya akivitas ekonomi diarahkan pada keterlibatan sebagian besar rakyat. Ekonomi rakyat dibedakan dari ekonomi konglomerat dalam sifatnya yang tidak kapitalistik. Ekonomi konglomerat yang kapitalistik menomorsatukan pengejaran keuntungan tanpa batas dengan cara bersaing, kalau perlu saling mematikan (free fight competition). Sebaliknya, dalam perekonomian rakyat semangat yang lebih menonjol adalah bekerja sama, karena hanya melalui kerja sama berdasar asas kekeluargaan tujuan usaha dapat dicapai ${ }^{11}$. Makna ekonomi kerakyatan adalah suatu perekonomian yang orientasinya pada keterlibatan orang banyak dalam aktivitas ekonomi, yakni aktivitas produksi, aktivitas konsumsi dan aktivitas distribusi. Fakta yang ada sangat berbeda, karena ekonomi kita terkonsentrasi pada segelintir pelaku ekonomi saja.

Dengan ketergantungan pada global dan kurang melibatkan ekonomi rakyat dalam ekonomi ini telah melahirkan ironi antara lain bisa dilihat dari data agraris

${ }^{11}$ Mubyarto (1988), Sistem dan Moral Ekonomi Indonesia (Jakarta: LP3ES), p. 40-46. 
Edy Suandi Hamid: Akar Krisis Ekonomi Global...

kita, dimana Indonesia yang sering menyebut sebagai negara agraris namun ketergantungan impor pangannya sangat tinggi, sebagaimana tercermin dalam Tabel 3.

Dengan pola pembangunan ekonomi yang kurang berpihak pada ekonomi rakyat itu pula pada akhirnya melahirkan fakta lain berupa kemiskinan dan pengangguran (lihat Tabel 4).

Tabel 3. Kebutuban Komoditas dan Perbandingan Pemenuban Kebutuban Nasional

\begin{tabular}{|l|l|}
\hline \multicolumn{1}{|c|}{ Komoditi } & \multicolumn{1}{c|}{$\%$ Terhadap Kebutuhan Nasional } \\
\hline Daging sapi & $25 \%( \pm 600.000$ ekor $)$ \\
\hline Gula & $30 \%( \pm 1,3$ juta ton $)$ \\
\hline Beras & $2 \%( \pm 1,2$ juta ton $)$ \\
\hline Bawang putih & $90 \%$ \\
\hline Kedelai & $70 \%( \pm 1,4$ juta ton $)$ \\
\hline Garam & $50 \%$ \\
\hline Jagung & $10 \%$ \\
\hline Kacang Tanah & $15 \%$ \\
\hline Susu & $70 \%$ \\
\hline
\end{tabular}

Sumber: Yudhobusodo (2008).

Tabel 4. Jumlah dan Presentase Penduduk Miskin di Indonesia 1996-2006

\begin{tabular}{|c|c|c|c|c|c|c|}
\hline \multirow{2}{*}{ Tahun } & \multicolumn{2}{|c|}{ Jumlah Penduduk Miskin (juta) } & \multicolumn{3}{c|}{ Presentase Penduduk Miskin } \\
\cline { 2 - 7 } & Kota & Desa & Kota+Desa & Kota & Desa & Kota+Desa \\
\hline $\mathbf{1 9 9 6}$ & 9,42 & 24,59 & 34,01 & 13,39 & 19,78 & 17,47 \\
\hline $\mathbf{1 9 9 8}$ & 17,60 & 31,90 & 49,50 & 21,92 & 25,72 & 24,23 \\
\hline $\mathbf{1 9 9 9}$ & 15,64 & 32,33 & 47,97 & 19,41 & 26,03 & 23,43 \\
\hline $\mathbf{2 0 0 0}$ & 12,30 & 26,40 & 38,70 & 14,60 & 22,38 & 19,14 \\
\hline $\mathbf{2 0 0 1}$ & 8,60 & 29,30 & 37,90 & 9,76 & 24,84 & 18,41 \\
\hline $\mathbf{2 0 0 2}$ & 13,30 & 25,10 & 38,40 & 14,46 & 21,10 & 18,20 \\
\hline $\mathbf{2 0 0 3}$ & 12,20 & 25,10 & 37,30 & 13,57 & 20,23 & 17,42 \\
\hline $\mathbf{2 0 0 4}$ & 11,40 & 24,80 & 36,10 & 12,13 & 20,11 & 16,66 \\
\hline $\mathbf{2 0 0 5}$ & 12,40 & 22,70 & 35,10 & 11,68 & 19,98 & 15,97 \\
\hline $\mathbf{2 0 0 6}$ & 14,49 & 24,81 & 39,30 & 13,47 & 21,81 & 17,75 \\
\hline $\mathbf{2 0 0 7} *$ & 13,56 & 23,61 & 37,17 & 12,52 & 20,37 & 16,58 \\
\hline
\end{tabular}

*= Maret 2007

Sumber: Diolah dari data Survei Sosial Ekonomi Nasional (Susenas) dikutip dalam Badan Pusat Statistik (2007).

Tabel 5. Indeks Gini

\begin{tabular}{|l|c|c|c|c|c|c|}
\hline Kelompok penduduk & $\mathbf{2 0 0 2}$ & $\mathbf{2 0 0 3}$ & $\mathbf{2 0 0 4}$ & $\mathbf{2 0 0 5}$ & $\mathbf{2 0 0 6}$ & $\mathbf{2 0 0 7}$ \\
\hline $40 \%$ terendah & 20,92 & 20,57 & 20,80 & 18,81 & 19,75 & 19,10 \\
\hline $40 \%$ menengah & 38,89 & 37,10 & 37,13 & 36,40 & 38,10 & 36,11 \\
\hline $20 \%$ teratas & 42,19 & 42,33 & 42,07 & 44,78 & 42,15 & 44,79 \\
\hline Indeks Gini & 0,33 & 0,32 & 0,32 & 0,36 & 0,33 & 0,37 \\
\hline
\end{tabular}

Sumber: BPS, dikutip dari Bank Indonesia (2008) Tabel 2.16.

Volume III, No. 1, Juli 2009 
Edy Suandi Hamid: Akar Krisis Ekonomi Global...

Sebenarnya, kalau kita lihat terdapat semangat untuk terus mengembangkan ekonomi kerakyatan, namun masih sebatas jargon atau komoditas untuk kampanye atau pencitraan. Parpol yang akan maju ke pemilu maupun para calon kepala daerah dalam program kerja, bahkan visi-misinya, hampir selalu menawarkan ekonomi kerakyatan sebagai bagian program kerja yang akan dilakukan. Namun sayangnya, hal itu lebih banyak sebagai upaya untuk mencari pendukung dengan menonjolkan bahwa parpol atau sang calon bersifat populis. Faktanya, umumnya program atau visi-misi itu tidak mewujud dalam program kerja riil manakala mereka sudah mendapatkan kekuasaan. Jadi, dalam praktik dewasa ini, ekonomi kerakyatan masih mengemuka sebagai jargon atau upaya untuk menarik simpati publik ketimbang implementasi yang secara substantif sejalan dengan ekonomi kerakyatan tersebut.

Hal demikian tentu tidak bisa dibiarkan berlanjut, dan pemikiran mengenai Ekonomi Pancasila ataupun ekonomi kerakyatan hanya berhenti sebagai norma atau jargon saja. Untuk itu, para pemikir dan mereka yang sepakat dengan ide almarhum Prof Mubyarto yang sangat intens memperjuangkan sistem ekonomi berbasis nilai-nilai lokal tersebut seyogianya terus mengkaji dan membumikan ide itu sehingga benar-benar bisa dilaksanakan dalam praktik ekonomi nasional. Pemikiran ekonomi kerakyatan, misalnya, harus bisa diperjelas dengan indikatorindikator kongkret sehingga orang tahu apakah kebijakan yang diambil sudah sesuai atau tidak sesuai dengan prinsip atau subsistem ekonomi kerakyatan. Masih seringkali terjadi orang atau birokrat yang berulang berbicara mengenai ekonomi kerakyatan namun sebenarnya pemahaman mereka berbeda dengan yang sering dibicarakan akademisi atau bahkan yang ada dalam Tap MPR yang mengatur ekonomi kerakyatan tersebut.

\section{Penutup}

Kondisi ekonomi dunia yang saat ini tengah menghadapi krisis keuangan global menunjukkan betapa kapitalisme sebagai sebuah sistem ekonomi telah banyak menyebabkan persoalan bagi ekonomi dunia. Hal ini merupakan akibat dari fondasi dasar dan paradigma keilmuan yang mendasarinya dipraktekkan berseberangan dengan nilai kemanusiaan dan mengingkari sejumlah ideologi dasarnya. Akibatnya berbagai masalah ekonomi terus menerus terjadi dan mengakibatkan banyak sumber daya yang terserap untuk mengatasinya. Ironisnya, dampak negatif dari sistem ini juga menimpa sebagian masyarakat dunia yang sebenarnya tidak banyak menikmati hasil positif dari sistem ekonomi tersebut. Oleh karena itu, meluruskan kembali ilmu ekonomi agar sesuai dengan filosofi dan realitas kehidupan manusia menjadi urgent dilakukan dan berbagai upaya telah dilaksanakan menuju ke arah tersebut.

Bagi Indonesia, meskipun memiliki kapasitas ekonomi yang lebih baik dibandingkan satu dasawarsa lalu, dampak krisis yang berlangsung tetap terasa. Hal ini merupakan momentum untuk mengevaluasi kembali kebijakan-kebijakan ekonomi yang selama ini bias pada paradigma kapitalis. Sudah saatnya bangsa Indonesia kembali menggali dan mengembangkan sistem ekonomi yang sesuai dengan jati diri dan budaya bangsa yang berakar pada nilai luhur bangsa Indonesia. Pilihan kembali pada ekonomi kerakyatan yang lebih menjamin berlakunya keadilan 
Edy Suandi Hamid: Akar Krisis Ekonomi Global...

sosial bagi segenap rakyat sudah saatnya diimplementasikan dalam kerangka kebijakan yang lebih nyata dan tidak sekedar jargon politik atau pun kampanye populis menjelang pemilu.

\section{DAFTAR PUSTAKA}

Badan Pusat Statistik, (2007), Berita Resmi Statistik No. 38/07/Th. X, 2 Juli 2007.

Bank Indonesia, (2008), Perkembangan Ekonomi Keuangan dan Kerjasama Internasional Triwulan III-2008, Jakarta: Bank Indonesia.

Callinicos, Alex, (2003), An Anti-Capitalist Manifesto, Cambridge: Polity Press.

Eichengreen, Barry, (2008), Anatomy of Financial Crisis dikutip dari http://www.voxeu. org/index. php?q=node/1684/ accessed 23 September 2008.

Khan, M. Fahim, (2008), World Financial Crisis :Lesson from Islamic Economics dikutip dari http://www.i-sei.org/ accessed 28 November 2008.

Mubyarto, (1988), Sistem dan Moral Ekonomi Indonesia. Jakarta: LP3ES.

(2003), Ekonomi Pancasila: Renungan Satu Tahun Pustep UGM. Yogyakarta: PUSTEP UGM.

Partomo, Wahyu, (2007), Ancaman Perlambatan dan Inflasi Amerika Serikat dalam Laporan Perkembangan Ekonomi Keuangan dan Kerja Sama Internasional Triwulan III 2007, Jakarta: Bank Indonesia, p. 83-92.

Stiglitz, Joseph, Capitalist Fools dikutip dari http://www.vanityfair.com/magazine/2009/01/stiglitz200901?print able=true\&currentPage $/$ acessed 10 Desember 2008.

The New York Time Review of Books, (2008), The Financial Crisis: An Interview with George Soros,15 Mei 2008 diakses pada 22 Oktober 2008.

Wikipedia, (2008), Financial crisis dikutip dari http://en.wikipedia.org/wiki/Financial_crisis/accessed 22 Oktober 2008.

Yudohusodo, Siswono, (2008), Politik Berwawasan Kebangsaan, makalah disampaikan dalam Simposium Nasional Peringatan 100 Tahun Kebangkitan Nasional, Yogyakarta, 19 Mei 2008. 